\title{
SYNTHESIS AND CHARACTERIZATION OF SUPERABSORBENT SODIUM ALGINATE-g-POLY (POTASSIUM ACRYLATE) HYDROGELS PREPARED BY USING GAMMA IRRADIATION
}

\author{
Erizal $^{1}$, Fajar Lukitowati ${ }^{1}$, Intan Oktaviani ${ }^{2}$, Dhena Ria Barleany ${ }^{3}$, \\ Basril Abbas ${ }^{1}$ and Sudirman ${ }^{4}$ \\ ${ }^{1}$ Centre for Application of Isotopes and Radiation, Jl. Lebak Bulus Raya No.49 Jakarta 12070. \\ ${ }^{2}$ Faculty of Pharmacy and Science, University Muhammadyah, Prof.Dr.Hamka \\ Jl. Delima II/IV, Klender Jakarta 13460 \\ ${ }^{3}$ Dept. Chemical Engineering, University Sultan Ageng Tirtayasa \\ Jl.Jend.Sudirman KM.3, Cilegon-Banten 42435 \\ ${ }^{4}$ Center for Science and Technology of Advanced Materials, Puspiptek, Serpong, Tangerang \\ E-mail: Erizal@batan.go.id
}

Received : 24 Maret 2017; revised : 10 April 2017; accepted : 29 Mei 2017

\begin{abstract}
SYNTHESIS AND CHARACTERIZATION OF SUPERABSORBENT SODIUM ALGINATE-g-POLY (POTASSIUM ACRYLATE) HYDROGELS PREPARED BY USING GAMMA IRRADIATION. The aim of this research was to use gamma rays as sources for the preparation of superabsorbent hydrogels through radiation induced copolymerization. A series of superabsorbent hydrogels were prepared from aqueous solution containing partially neutralized acrylic acid (15\%) with different sodium alginate $(\mathrm{NaAlg})$ concentrations $(0.5 \%$ to $1.5 \%$ ) by ionizing gamma irradiation ( $10 \mathrm{kGy}$ to $40 \mathrm{kGy}$ ) at room temperature. The effect of NaAlg concentration and irradiation doses on the water absorption behavior of the obtained hydrogels was investigated. The structural changes of hydrogels were characterized using Fourier Transform Infrared (FTIR) whereas the morphologies of hydrogels were examined using Scanning Electron Microscope (SEM). The results showed the swelling of hydrogel in water and $\mathrm{NaCl}$ solution increases with increasing $\mathrm{NaAlg}$ concentration and decreases with increasing irradiation dose up to $40 \mathrm{kGy}$. The extend of gel fraction increases as a function of NaAlg concentration. The results of FTIR analysis revealed that acrylic acid and sodium alginate had been successfully grafted, while SEM examination showed that the hydrogels demonstrated large numbers of pores-.
\end{abstract}

Keywords: Hydrogel, Superabsorbent, Sodium alginate, Irradiation, Grafting

\section{ABSTRAK}

SINTESIS DAN KARAKTERISASI HIDROGEL SUPERABSORBENT NATRIUM ALGINATE-G-POLY (KALIUM AKRILAT) MENGGUNAKAN IRADIASI GAMMA. Tujuan penelitian adalah memanfaatkan sumber radiasi gamma untuk membuat hldrogel superabsorben melalui reaksi induksi kopolimerisasi. Satu seri hidrogel superabsorben disintesis dari campuran asam akrilat yang dinetralkan sebagian dengan beragam konsentrasi (0,5\% sampai 1,5\%) natrium alginat ( $\mathrm{NaAlg}$ ) dan diiradiasi pada beragam dosis (10 kGy sampai $40 \mathrm{kGy}$ ) pada suhu kamar. Pengaruh konsentrasi $\mathrm{NaAlg}$ dan dosis iradiasi terhadap kemampuan menyerap air hidrogel diinvestigasi. Perubahan struktur kimia hidrogel diukur menggunakan Fourier Transform Infra Red (FTIR) sedangkan morfologi hidrogel diuji dengan Scanning Electron Microscope (SEM). Nisbah penggembungan hidrogel dalam air dan larutan NaCL meningkat dengan meningkatnya konsentrasi NaAlg dan menurun dengan meningkatnya dosis iradiasi hingga 40 kGy. Fraksi gel hidrogel meningkat sebagai fungsi waktu. Hasil pengujian spektrum FTIR mengkonfirmasi kemungkinan terjadinya reaksi pencangkokan antara asam akrilat dengan $\mathrm{NaAlg}$, dan hidrogel berpori-pori relatif besar ditunjukkan dari hasil pengujian SEM.

Kata kunci: Hydrogel, Superabsorben, Natrium alginate, Iradiasi, Cangkok

\section{INTRODUCTION}

Nowadays, the need to the materials that have good performance in absorbing a large amount quantity of water or liquid very interesting objects for researchers. One of such ma- terials is the synthetic hydrogel matrices which comprise water insoluble, but water swellable crosslinked hydrophilic polymers. These materials are known as hydrogel superabsorbent 
(HSA), originated in the United States as water retention agents in agriculture, and developed in Japan in middle 1970s in the personal care and hygienic products such as surgical pads, hot and cold theraphy packs, medical waste solidification, disposable diapers and sanitary napkins (Buchholz and Graham 1998). Moreover, they are used as artificial soils for hydrophonics in soil conditioning, as drug delivery systems agents for pharmaceuticals or agrochemicals and the numerous applications (Abd El-Rehim et al. 2004; Chang et al. 2010; Hosseinzadeh et al. 2004; Paulino et al. 2006; Li et al. 2007; Barleany et al. 2013; Erizal et al. 2010; Tomar et al. 2007; Bakass et al. 2002).

In recent years, research on HSA have been intensively focused on some types of basic materials such as acrylic acid (AA) and acrylamide (AAM) monomers and its copolymers (Chang et al. 2010). However, the disadvantage of HSA based on monomers/polymers synthetic that is not biodegradable which will cause environmental problems. Hence, the development of multi-component superabsorbent derived from natural polymer and ecofriendly additives is subject of great interest due to their unique commercial and environment advantages and such materials have also been honored as the material families of "in greening the 21 st century materials world "

Biodegradable polymers have been used for the preparation of hydrogels. Among these compounds, alginates as naturally occur-ring polysaccharides is very attractive, because its may form physical gels under specific conditions. Alginate, a water-soluble linear polymer obtained from brown algae, is composed of (1-4)-b-Dmannuronic acid (M) and (1-4)-a-L-guluronic acid $(G)$ units in the form of homopolymeric (MM- or GG-blocks) and heteropolymeric sequences (MG- or GM-blocks). Based on their gelling ability, stabilizing properties and high viscosity in aqueous solutions, alginates and their derivatives like sodium alginates are widely used in the food, cosmetics and pharmaceutical industries. In addition, NaAlg can be easily modified through various chemical or physical methods such as grafting copolymerization with hydrophilic vinyl monomers (Isiklan et al. 2010), polymer blending and compounding with other functional components (Hua and Wang 2009). The physico-chemical properties of NaAlg is almost dominated from their functional groups (-OH and -COO-) that have great affinity for water molecules. Therefore, it is expected that the new of HSA with improve structure and performance can be developed by the effective combination of $\mathrm{AA}$ with $\mathrm{NaAlg}$ via gamma radiation technique.

In the present work, a series hydrogel superabsorbent of copoly (AA)-NaAlg containing $15 \%$ AA with different NaAlg concentrations
(0.5\% until $1.5 \%)$ were prepared using gamma irradiation in the range from $10 \mathrm{kGy}$ up to $40 \mathrm{kGy}$ (dose rate. $5 \mathrm{kGy} / \mathrm{h}$ ). Effect different NAAlg concentrations and irradiation doses on swelling ratio was in-vesttigated, and gel fraction was determined gravimetrically from the obtained hydrogels. The chemical changes of hydrogels was characterized by using FTIR and SEM.

\section{MATERIAL AND METHODE}

\section{Material}

Acrylic acid in glacial form was purchased from Merck, Damrstadt, Germany and was stored in a refrigerator before use. Potassium hydroxide $(\mathrm{KOH})$ was obtained from Merck and used for partially neutralization of acrylic acid. Sodium chloride $(\mathrm{NaCl})$ was also purchased from Merck. Sodium Alginate was obtained from Keshida, Japan. Distilled water was used in the polymerization and swelling experiment. All of the reagents were analytical grade used without purification.

\section{Characterization}

In order to confirm the crosslinking of the hydrogels, the characterization was performed by using Fourier Transform Infra Red (FTIR), Shimadzu Prestige-21, spectrometer model 800 series Japan. The surface morphology of hydrogels was studied by using filed emission Scanning Electron Microscope (SEM) using JSM 6510 equipment (JEOL, Japan), with operating voltage of $30 \mathrm{kV}$. Samples of hydrogels were immersed in distilled water at room temperature until reached maximum swelling, then frozen at $-80^{\circ} \mathrm{C}$ and lyophilized. The freeze drying hydro-gels were fixed on brass holder and coated by sputtering with a thin Au layer in order to avoid charging effects.

\section{Preparation of hydrogels}

Crosslinked hydrogels were prepared by using gamma radiation from cobalt -60 . A series acrylic acid solution were prepared from $15 \mathrm{~mL}$ acrylic acid dissolved in $50 \mathrm{~mL}$ distilled water, and then partially neutralized with $\mathrm{KOH}$ at a degree neutralization 0.50 (mole,\%). NaAlg solution $(50 \mathrm{~mL})$ at different concentrations ranging from $0.5 \%$ up to $1.5 \%$ were poured into the acrylic acid solution, then homogenized, respectively. The mixture solutions were poured into double polypropylene (PP), packed, then irradiated using gamma rays at the doses ranging from $10 \mathrm{kGy}$ up to 40kGy (dose rate $5 \mathrm{kGy} / \mathrm{h}$ ) at room temperature in the irradiator Panorama, CAIR BATAN, Jakarta. The hydrogels were dried at $60{ }^{\circ} \mathrm{C}$ for $48 \mathrm{~h}$, and milled up to 60 mesh until 80 mesh. 


\section{Swelling measurements}

Swelling ratio of HSA were determined by using gravimetric method. The dried HSA (Wo) in distilled water (or other solution), shaked with $400 \mathrm{rpm}$ rate at interval time in the range of seconds or minutes at room temperature. At a predetermined time interval, the water containing the swollen HSA were filtered using stainless steel sieves $( \pm 200$ mesh) and the hydrogels were hanging for approximately $1 \mathrm{~h}$ until no more water drop off. The remaining volume of water was collected and water absorption of hydrogels was measured as $W_{t}$. Swelling ratio of hydrogels calculated as follows

$$
\text { Swelling ratio }=\frac{W_{t}}{W_{0}}
$$

Where $W_{0}$ and $W_{t}$ are the weights of dried hydrogel and water absorption (g) at time t. Equlibrium degree swelling (EDS) of HSA were determined after the dried samples were swollen at $24 \mathrm{~h}$ immersing time in destilled water. The EDS and swelling ratio of hydrogels in saline solution was calculated using swelling ratio equation as described above (eq.1).

\section{RESULT AND DISCUSSION}

\section{Swelling of hydrogels}

Effect of sodium alginate concentration on the swelling capacity of NaAlg-g-poly (potassium acrylate) superabsorbent hydrogels as a function of immersion time is presented in Figure 1. It can be seen that at an initial immersion times at $15 \mathrm{sec}$, all the hydrogels show remarkable high water absorption capacity ranging from $250 \mathrm{~g} / \mathrm{g}$ to $330 \mathrm{~g} / \mathrm{g}$. With increasing immersion time up to $360 \mathrm{sec}$ and sodium alginate concentration from 0.5 up to $1.5 \%$, the swelling ratios of hydrogels gradually increases and then reached a cons-tant value in the range of $300 \mathrm{~g} / \mathrm{g}-450 \mathrm{~g} / \mathrm{g}$.

Sodium alginate (NaAlg) is known as polysaccharides derivative compounds consisting of a large number free hydroxyl $(\mathrm{OH})$ and carboxyl $(\mathrm{COOH})$ groups along its polymer backbones which makes it a better candidate for chemical modification (Lee and Mooney 2012). In addition, monomer acrylic acid which has one double bond active and carboxyl $(\mathrm{COOH})$ as hydrophilic groups are easily binding with hydroxyl groups of water molecules to form hydrogen bonds. However, when partially neutralized acrylic acid irradiated in aqueous solution crosslinked polymer occurs. However, when the NaAlg solution was mixed with acrylic acid solution, the hydrogen bonding will occurs between of these two compounds and $\mathrm{NaAlg}$ dissolved in acrylic acid solution. So, when an aqueous solution of acrylic acid (AA) in the presence NaAlg was irradiated using gamma rays, the radical polymerization reaction will occur in aqueous solution. Some researcher reported the possible mechanisms reaction of irradiated acrylic acid in aqueous solution (Erizal et al.2015) and reactions between poly (acrylic acid) with natural polymers (Davidenko et al., 2007, Trong et al. 2002). Therefore, the presumptive mechanism reactions for the preparation of hydrogels of NaAlg-g- poly(potassium acrylate) is illustrated in Figure 2 and Figure 3.

The partially neutralized of acrylic acid will change to become its radicals and then polymerized to be such as homopolymers (eq. 4) and cross-linked copolymers (eq.5). At the same time, the NaAlg was also underwent the effect of gamma irradiation and then formed its radicals (eq.6). Because of the copolymer acrylic acid radicals relatively stable, it will graft onto $\mathrm{NaAlg}$ polymer radicals to form crosslinked structures (eq.7). As a result, the anions and its molecules of poly(acrylate acid) along polymer backbones interacts with hydroxyl groups of sodium alginate through hydrogen bonding (Figure 3 ) and the ratio swelling of hydrogels decreased. In contrast, when the sodium alginate concentration increased in the mixture, the swelling ratio increased caused of the increase hydroxyl groups in the hydrogel matrices.

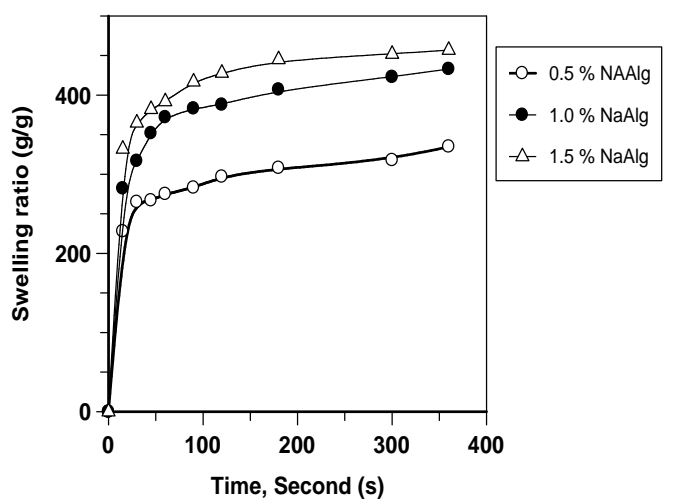

Figure 1. Effects of immersing time on the swelling ratio of NaAlg -g- poly (potassium acrylate) hydrogels at different NaAlg concentrations $(0.5 \%$ until $1.5 \%)$ prepared at irradiation dose $10 \mathrm{kGy}$. 


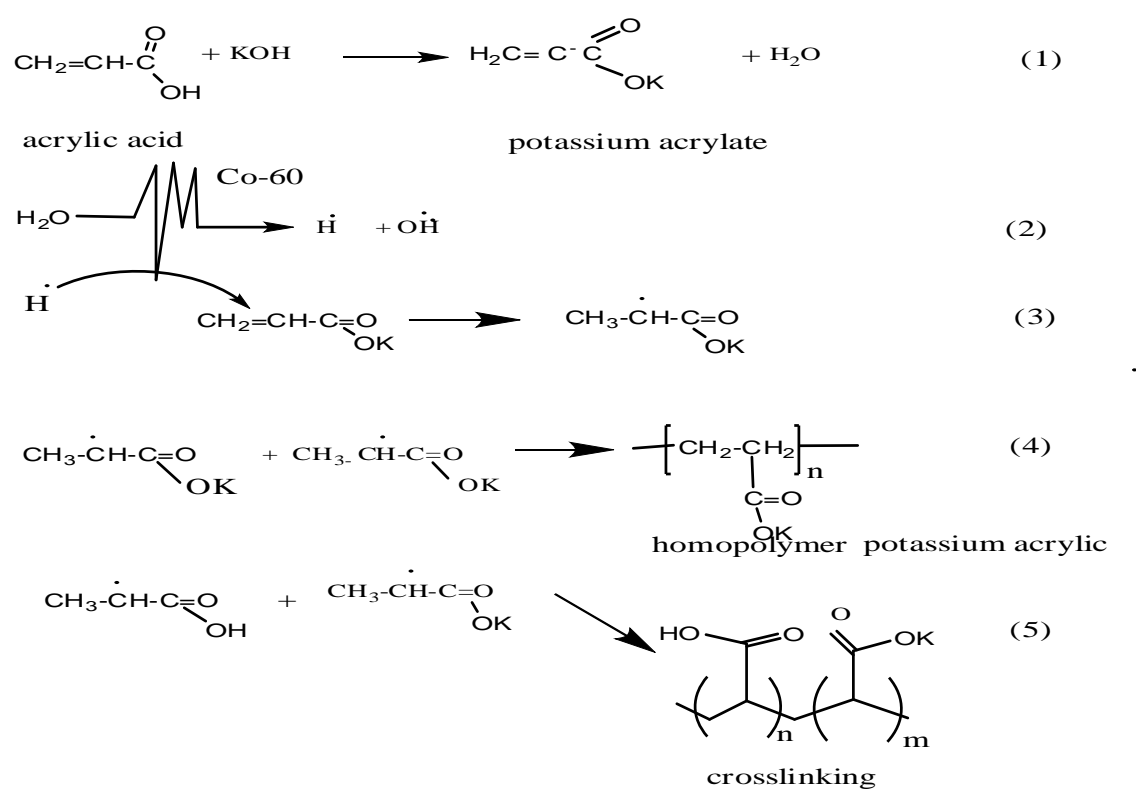

Figure 2. The presumptive mechanism reaction of potassium acrylate irradiated by using gamma rays (Erizal et .al. 2015)
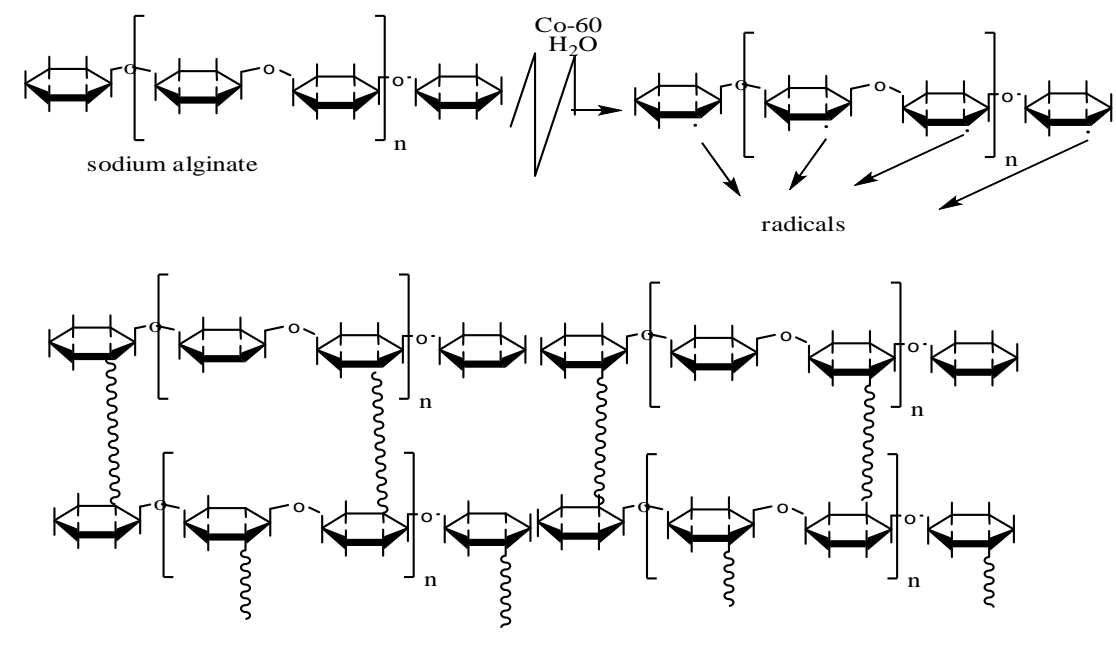

几 poly ( potassium acrylate)

Figure 3. The possible mechanisms reaction for the synthesis of NaAlg -g- poly (potassium acrylate) copolymers hydrogels via gamma radiation.(Trong et al. 2002)

\section{Gel Fraction of hydrogels}

The gel fraction parameter of hydrogels is indirect reflection the efficiency of irradiation synthesis reactions and degree crosslinking of hydrogels. The effect of NaAlg concentrations on the gel fraction of hydrogels prepared using irradiaton dose at $10 \mathrm{kGy}$ is shown in Figure 4. It can be seen that with increasing $\mathrm{NaAlg}$ concentrations from $0 \%$ up to $1.5 \%$, the gel fraction of hydrogel increases up to approximately $90 \%$.

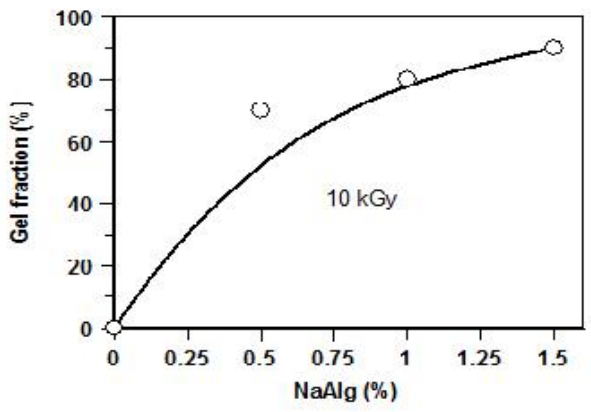

Figure 4. Effect NaAlg concentrations on gel action of hydrogels prepared using irradiation at 10 kGy 
It is indicated that NaAlg molecules can be crosslinked with acrylic acid through radiation processing effectively. In addition, the rest of the mixture around $10 \%$ might be remaining as unreacted products such as dissolved monomers, peroxides, and unreacted NaAlg polymers.

\section{EDS of hydrogels}

When the hydrogels are immersed in water, the surfaces area of hydrogels will be contacted and wetted by water. Interactions between water and hydrogel are occurred via hydrogen bonding or ionic bond. The coil of hydrogels gradually loosen its structure, which makes the possibility interaction between water and hydrogels increases then the pores of hydrogel gradually opened. As the results, water will in and out from the pores of hydrogels and then at a certain time are reached equilibrium condition called as equilibrium degree of swelling (EDS). The effect of different irradiation doses on the EDS of hydrogels measured at $24 \mathrm{~h}$ is shown in Figure 5. With increasing irradiation dose up to $40 \mathrm{kGy}$, the EDS of hydrogels decreases from $600 \mathrm{~g} / \mathrm{g}$ up to $450 \mathrm{~g} / \mathrm{g}$. It is indicated with increasing irradiation dose, the crosslink density of hydrogels increases and the capacity of hydrogels to absorp water decrease.

\section{Swelling hydogel in the physiologis solution \\ In general, the aim of the prepared of} hydrogels superabsorbent in the world was mainly for the application as baby diapers. The HSA used for baby diapers segment is growing at CAGR of $5.2 \%$ and constitutes a significant part of overall superabsorbent polymer market research. Morever, swelling capacity of superabsorbent hydrogels are normally tested in salt solutions which is the one of important parameters in many practical applications such as personal hygiene products and water release systems in agriculture. In general, the swelling capacity of hydrogels in $\mathrm{NaCl}$ solution decreased compared to the swelling values in distilled water. This is because in salts solution the osmotic pressure resulting from the difference in the mobile ion concentration between gel and the aqueous phases is decreased and consequently the absorbency amounts are diminished. However, the hydrogels with higher swelling capacity in salts solution will be promising products in the future for diapers in particularly..

In this experiment, the effect $\mathrm{Na} \mathrm{Alg}$ concentrations on the swelling of hydrogels in $0.9 \%$ aqueous $\mathrm{NaCl}$ solution is presented in Figure 6. It can be seen that with increasing NaAlg concentration up to $1.5 \%$, the swelling ratio of hydrogels increases up to approximately $40 \%$. It suggests that the swelling ratios of hydrogels in $\mathrm{NaCl}$ solution indirectly followed the

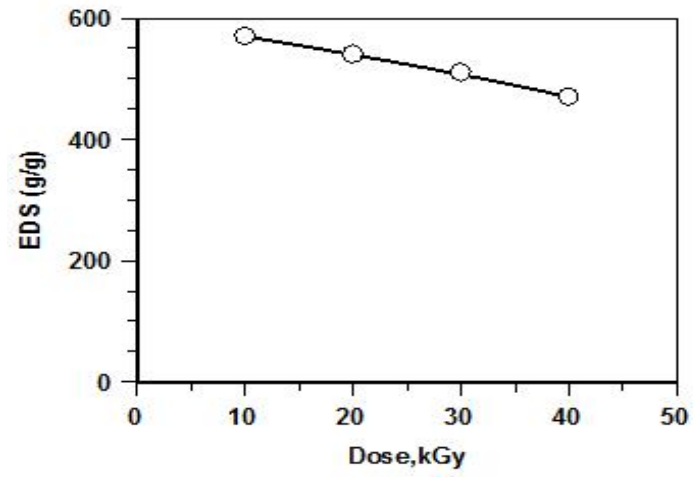

Figure 5. The effect irradiation dose on the equillibrium degree swelling of hydrogels with $0.5 \%$ NaAlg concentration prepared by using gamma irradiation

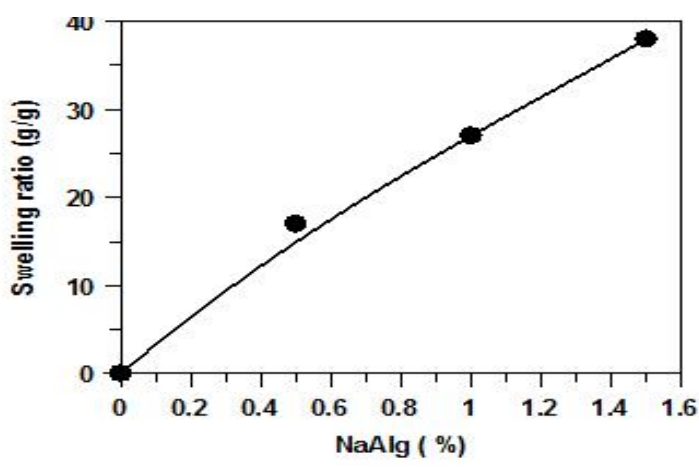

Figure 6. The effect of NaAlg concentrations on the swelling hydrogels in $0.9 \% \mathrm{NaCl}$ solution. The hydrogel with NaAlg $0.5 \%$ prepared by using gamma at a dose of $10 \mathrm{kGy}$

ability of hydrogels to absorb water, which makes the swelling ratio of the hydrogel increased as the NaAlg concentration in the hydrogel increased.

Wang et al, 2010, reported that water absorption of poly(sodium acrylic)-g-sodium alginate hydrogels in water and saline solution was also greatly improved with increasing the content of NaAlg up to 11.08 wt\% and beyond $11.08 \mathrm{wt} \%$, the water absorption of hydrogels reduced.

\section{FTIR Characterization}

The Fourier transform infrared (FTIR) of the sodium alginate ( $\mathrm{NaAlg}$ ) and poly (acrylic acid)-g-NaAlg hydrogels were recorded and compared (Figure 7). Spectrum NaAlg (Fig 7a) showed impor-tant absorption bands regarding hydroxyl-,ether, and carboxylic functional groups. Stretching vibrations of $\mathrm{O}-\mathrm{H}$ bands of alginate appeared in the range $3000 \mathrm{~cm}^{-1}$ until $3600 \mathrm{~cm}^{-1}$. Stretching vibrations of aliphatic $\mathrm{C}-\mathrm{H}$ were observed at $2920 \mathrm{~cm}^{-1}$ until $2850 \mathrm{~cm}^{-1}$, observed 
bands in $1649 \mathrm{~cm}^{-1}$ and $1640 \mathrm{~cm}^{-1}$ were attributed to asymmetric and symmetric stretching vibrations of carboxylate salt ion, respectively. Comparing with the spectrum of $\mathrm{NaAlg}$, the spectrum NaAlg (Figure 7b) showed the absorption bands at $1612 \mathrm{~cm}^{-1}$ and $1417 \mathrm{~cm}^{-1}$ for the $-\mathrm{COO}$ shift to the bands at $947 \mathrm{~cm}^{-1}$ and $892 \mathrm{~cm}^{-1}$, respectively, and the absorption spectrum at 947 and $892 \mathrm{~cm}^{-1}$ disappeared in the IR spectrum of NaAlg-gpoly(potassium acrylate) suggesting the grafting reaction of acrylic acid on NaAlg (Hua and Wang 2009).

\section{SEM photographof HSA}

The SEM photograph provides the pores geometry and size related to their specific location of the hydrogels. Therefore, it gives relevant information the homogeneity and heterogenity of the hydrogels network. For this purpose SEM pictures of hydrogel which contents $0.5 \%$ NaAlg concentration prepared by using gamma irradiation were taken at the surface and interior of the hydrogels are shown in Figure 8. It can be seen that the hydrogel is covered by irregular pores with sizes ranging from $7.5 \mu \mathrm{m}$ up to $100 \mu \mathrm{m}$, and in some places covered by a thin skin of polymer. The presence of a polymeric skin has been describe for other hydrogel, and is probably related to the collapse of surface pores by a freeze drying process mainly in the hydrogels with large pores and thin walls. The pores of hydrogels provide water absorbing sites and resulting the penetration of water into the hydrogels network becomes easy and the swelling capacity of the resultant hydrogel enhanced substantially.

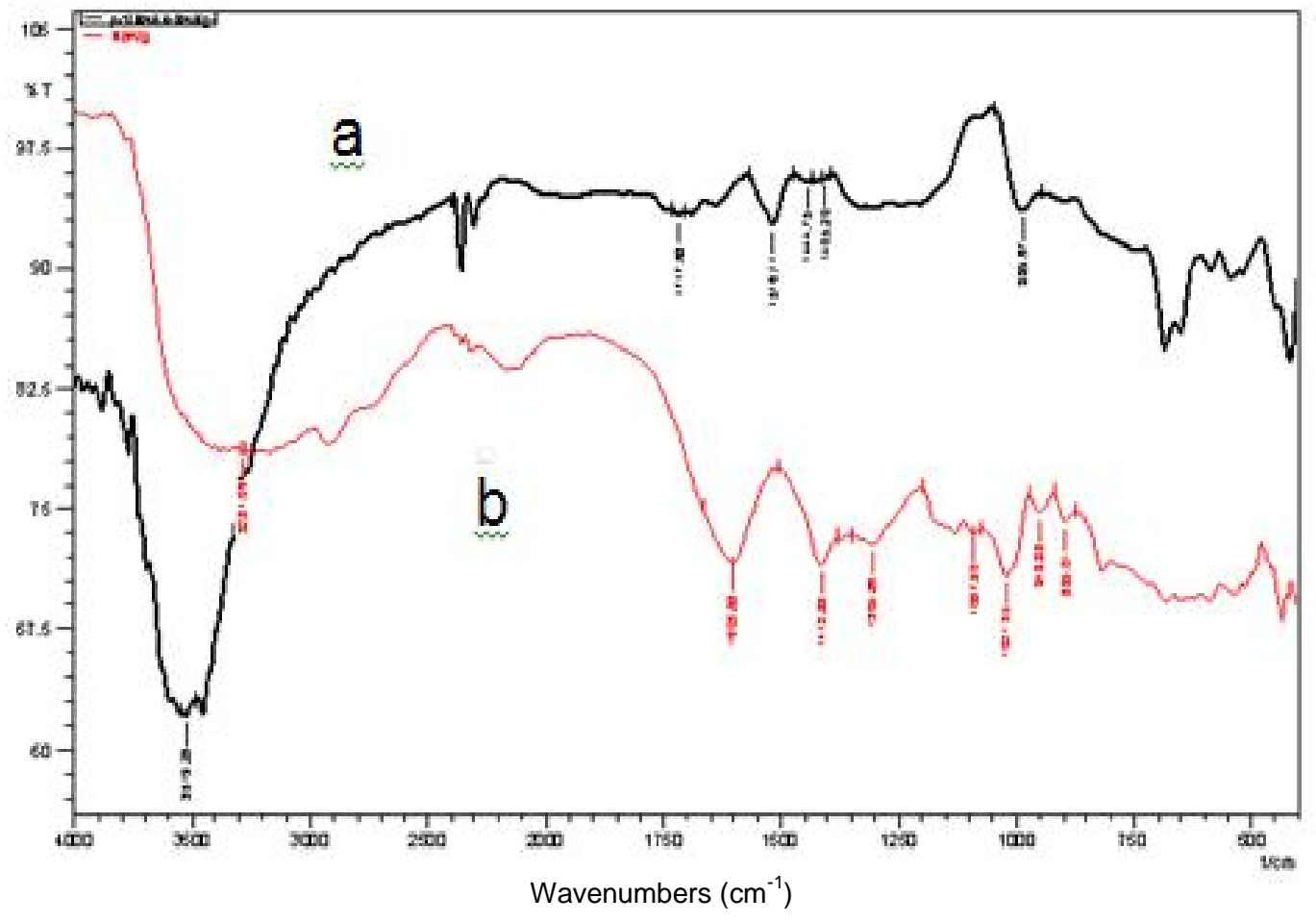

Figure 7. FTIR spectra of the polymers a) NaAlg; b) NaAlg-g-poly (potassium acrylate) copolymer 

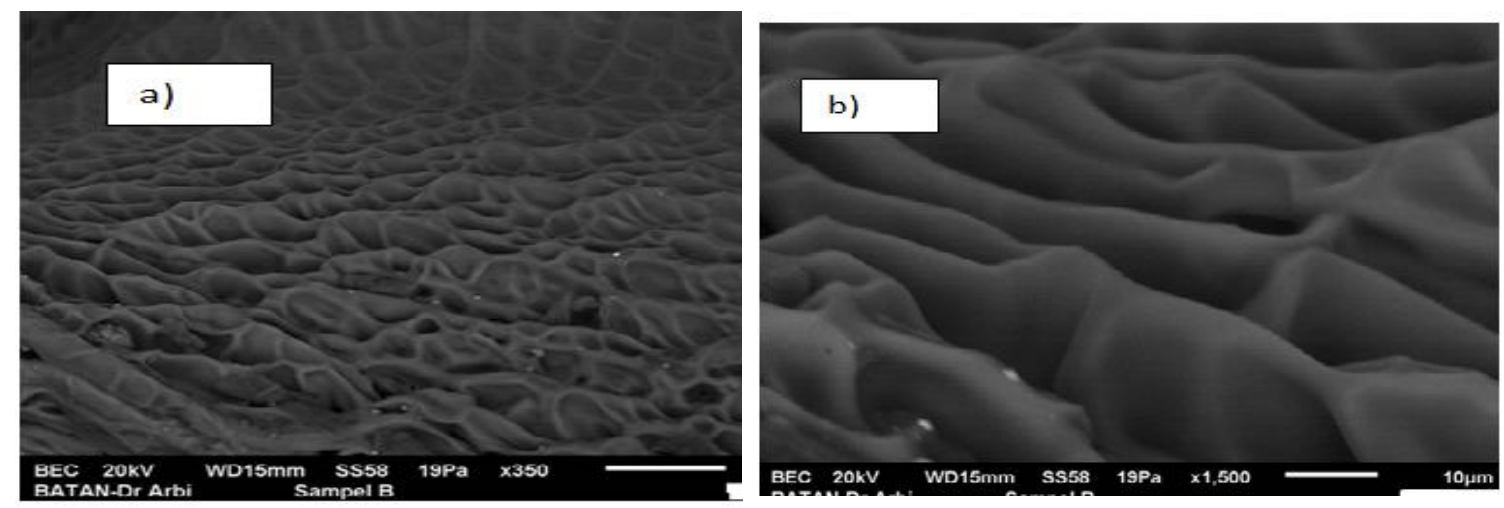

Figure 8. The scanning micrograph of the surface of NaAlg-g- (potassium acrylate) hydrogels prepared by using irradiation were taken with a magnification ; a) 350x and b) 1500x (the scale bar are $50 \mu \mathrm{m}$ and $10 \mu \mathrm{m}$ )

\section{CONCLUSION}

Superabsorbent hydrogels copoly (acrylic acid)-NaAlg can be synthesized through gamma irradiation. The swelling behavior and gel fraction of HSA dependent on NaAlg concentration and irradiation dose. With increasing NaAlg content in hydrogels, the swelling capacity of hydrogels in saline solution is increased. SEM micrograph showed large pore of hydrogels.

\section{AKCNOWLEGDMENT}

We wish to thank to Mr. Bonang for his valuable technical support on this research project specially of sample preparation for irradiation and Drs. Sulistioso G.S. for his SEM measurements.

\section{REFERENCES}

Abd El-Rehim, H.A., E.S.A. Hegazy, and H. L. Abd El-Mohdy 2004. Radiation synthesis of hydrogels to enhance sandy soil, water retention and increase plant performance. Journal applied polymer science 93: 1360-137.

Buchholz, F.L. and A.T. Graham .1998. Modern super-absorbent Polymer Technology. New York: Wiley VCH.

Bakass, M., A. Mokhlisse, and M. Lalleman. 2002. Absorption and desorption of liquid water by a superabsorbent polymer. Effect of polymer in the drying of the soil and quality of certain plants. Journal applied polymer science 83: 234-243.

Barleany D.A., Sofiyati, Unayah, and Erizal. 2013. The application of superabsorbent hydrogels copoly (acrylic acid - hydroxy ethyl acrylic) prepared using gamma radiation for $\mathrm{Cu} 2+$ ions adsorption in aqueous solution. Journal of waste management tecnology 16: 63-72

Chang C., B. Duan, J. Cai, and L. Zhang. 2010. Superabsorbent hydrogel based on cellulose for smart swelling and controlable delivery. European polymer journal 46: $92-100$

Davidenko,N., C.Peniche, J.M.Díaz, J.San Roman and R. Sastre. 2007. Photopolymerisation of acrylic acid and chitosan gels (I). Influence of preparation method on the formation and kinetic behaviour of interpenetrating complexes. Latin american applied research 37: 247-253.

Erizal. 2010. Synthesis and characterization of superabsorbent hydrogels poly(acrylamide-co- acrylic acid) using radiation techniques. A Scientific journal of application Isotopes and Radiation 6(2): 105-116.

Erizal, E., B.Abbas, S.G. Sukaryo, D.R.Barleany. 2015. Synthesis and Characterization Superabsorbent Hydrogels of Partially Neutralized Acrylic Acid Prepared Using Gamma Irradiation; Swelling And Thermal Behavior. Indonesian journal of chemistry 15(3): 281-287.

Hosseinzadeh,H., A.Pourjavadi and J.Zohuriaan. 2004. Modified carrageenan. 2 Hydrolyzed crosslinked kappa carrageenan-g -PAAm as a novel smart superabsorbent hydrogel with low salt sensitivity. J. Biomater Sci. Polym. 15(12): 1499-1511.

Hua, S. and A.Wang. 2009. Synthesis, characterization, and deswelling behavior of sodium alginate-g-poly-(acrylic acid)/sodiumhumate superabsorbent. Carbohy-drate polymers 75: 79-84.

Isiklan,N., F.Kursun, M.Inal. 2010. Graft copolymerization of itaconic acid onto 
sodium alginate using benzoyl peroxide. Carbohydrate polymers 79(3): 665-672.

Lee, K.Y. and D.J.Mooney. 2012. Alginate: Properties and Biomedical Applications. Progress Polym.Sci. 37(1): 106-126.

Li, A., J.Zhang, and A.Wang. 2007. Utilization of starch and clay for the preparation of superabsorbent composite. Bioresource technology 98: 327-333.

Paulino, A.T., R.A.Guilorme, G.M.Compesse, E.Z.Muniz, and J.Nozaki. 2006. Removal of methylene blue from an aqueous media using superabsorbent hydrogel supported on modified polysaccharide. Journal colloid interface science 30: 55-62.

Tomar, R.S., I.Gupta, R.Singhal, and A.K. Nagpal, 2007. Synthesis of poly- (acrylamide co-acrylic acid)-based superabsorbent hydrogels by gamma radiation: study of swelling behaviour and network para-meters. Designed Monomers and Poly-mer 10: 49-66.

Trong, M.D. Y.C. Chung, and Y.C. Wen. 2002, studies on degradation behavior of Chitosan -g- poly (acylic acid) copolymers, Tamkang journal science and engineering 5(4): 235-240'

Wang, W. and A. Wang. 2010. Synthesis and swelling properties of $\mathrm{pH}$-sensitive semi -IPN superabsorbent hydrogel based on sodium alginate-g-poly (sodium acrylate) and polyvinylpyrrolidone, Carbohydrate Polymers 80: 1028-1036. 